\title{
PERILAKU PENJAJA PANGAN JAJANAN ANAK SEKOLAH TERKAIT GIZI DAN KEAMANAN PANGAN DI JAKARTA DAN SUKABUMI
}

(Behaviour of School-food Vendor Related to Nutrition and Food Safety in Jakarta and Sukabumi)

\author{
Ghaida Yasmin ${ }^{1}$ dan Siti Madanijah ${ }^{1 *}$
}

1 Departemen Gizi Masyarakat, Fakultas Ekologi Manusia, Institut Pertanian Bogor, Bogor 16680.

* Alamat korespondensi: Departemen Gizi Masyarakat, Fakultas Ekologi Manusia, Institut Pertanian Bogor, Bogor 16680. Telp: 0251-8621258; Fax: 0251-8622276, Email: smadanijah@yahoo.co.id

\begin{abstract}
The purposes of this research were to identify and to analyze behaviour of school-food vendor related to nutrition and food safety in Jakarta and Sukabumi. This research used secondary data from Survey "National Monitoring and Verification Food Safety of Elementary Student Street-food 2008" by SEAFAST and BPOM RI. The subjects of this research are 79 school-food vendors in Jakarta and 29 school-food vendors in Sukabumi. Descriptive statistical method is used to process all the data. Most of the subjects were elementary school graduated (46.3\%) and used handcart as tool for sale of street-foods (31.5\%). Only $35.2 \%$ had attended a food safety education/training program. As the result of it, $48.1 \%$ of the subjects had sufficient nutrition and food safety knowledge. There were significant differentiation of nutrition and food safety knowledge between the subjects which had been classified by vendor group, level of education, and participation in food safety education/ training program. As many as $74.1 \%$ of the subjects lack of food safety practices. There were significant differentiation of food safety practices between the subjects which had been classified by vendor group, region, and level of education. Spearman's correlative test shows that there a positive correlation between level of education with nutrition and food safety knowledge, level of education with food safety practices. Pearson correlative test shows that there was no significant correlation between nutrition and food safety knowledge with food safety practices.
\end{abstract}

Key words: Behaviour, school-food Vendor, food safety.

\section{PENDAHULUAN}

Pangan jajanan merupakan salah satu jenis makanan yang sangat dikenal dan umum di masyarakat, terutama anak usia sekolah. WHO (1996) mengartikan pangan jajanan sebagai makanan dan minuman yang dipersiapkan dan/atau dijual oleh pedagang kaki lima di jalanan dan tempat-tempat keramaian umum lain yang langsung dimakan atau dikonsumsi kemudian tanpa pengolahan atau persiapan lebih lanjut. Anak sekolah biasanya membeli pangan jajanan pada penjaja pangan jajanan di sekitar sekolah atau di kantin sekolah. Oleh karena itu, penjaja berperan penting dalam penyediaan pangan jajanan yang sehat dan bergizi serta terjamin keamanannya.

Berdasarkan hasil Monitoring dan Verifikasi Profil Keamanan Pangan Jajanan Anak Sekolah (PJAS) Nasional tahun 2008 yang dilakukan oleh SEAFAST dan Badan POM RI, sebagian besar (>70\%) penjaja PJAS menerapkan praktik keamanan pangan yang kurang baik (Andarwulan, Madanijah, \& Zulaikhah, 2009). Perbedaan wilayah sekolah dasar seperti misal- nya antara Jakarta dan Sukabumi dapat mempengaruhi perilaku penjaja PJAS. Jakarta sebagai kota metropolitan yang mewakili wilayah perkotaan dan Sukabumi yang mewakili wilayah pedesaan memiliki kondisi lingkungan sosial, ekonomi, dan budaya yang berbeda yang selanjutnya dapat mempengaruhi perilaku penjaja PJAS.

Perilaku gizi dan keamanan pangan penjaja PJAS yang baik sangat penting dalam menentukan pangan jajanan yang aman dan sehat bagi anak sekolah. Namun dengan adanya perbedaan karakteristik penjaja dan wilayah maka perlu dikaji lebih lanjut perilaku penjaja PJAS yang terkait dengan gizi dan keamanan pangan.

Penelitian ini dilakukan dengan tujuan untuk mengetahui dan menganalisis perilaku penjaja pangan jajanan anak sekolah di Jakarta dan Sukabumi, serta menganalisis perbedaan pengetahuan serta praktik gizi dan keamanan pangan berdasarkan kelompok penjaja, wilayah, dan karakteristik penjaja PJAS (tingkat pendidikan dan keikutsertaan dalam 
penyuluhan keamanan pangan). Selain itu, penelitian ini juga bertujuan untuk menganali sis hubungan antara tingkat pendidikan dengan pengetahuan gizi dan keamanan pangan; tingkat pendidikan dengan praktik keamanan pangan; serta pengetahuan gizi dan keamanan pangan dengan praktik keamanan pangan

\section{METODE PENELITIAN}

\section{Desain, Tempat, dan Waktu}

Desain penelitian ini yaitu cross-sectional study. Penelitian ini menggunakan data sekunder yang berasal dari Survei "Monitoring dan Verifikasi Profil Keamanan Pangan Jajanan Anak Sekolah (PJAS) Nasional Tahun 2008" yang dilakukan oleh SEAFAST dan Badan POM RI. Data yang digunakan pada penelitian ini berasal dari SD di Jakarta dan Sukabumi. Analisis data sekunder dilakukan bulan Juni 2010.

\section{Jumlah dan Cara Pemilihan Subjek}

Penelitian ini mengkhususkan pada wilayah Jakarta dan Sukabumi dengan total 65 SD dengan rincian 18 SD di Sukabumi dan 47 SD di Jakarta. Contoh dalam penelitian ini adalah penjaja PJAS baik yang berada di kantin (pengelola kantin) maupun yang berada di sekitar SD (penjaja luar). Jumlah total contoh yaitu sebanyak 108 contoh dengan rincian 29 orang penjaja PJAS di Sukabumi dan 79 orang penjaja PJAS di Jakarta. Pemilihan penjaja luar sebagai unit contoh dipilih berdasarkan jenis kelompok PJAS sedangkan pemilihan pengelola kantin sebagai unit contoh dilakukan secara purposive sampling.

\section{Jenis dan Cara Pengumpulan Data}

Data yang dikumpulkan berupa data sekunder. Dalam survei tersebut, dilakukan wawancara dengan teknik face-to-face interview dan observasi langsung terhadap penjaja PJAS di lingkungan sekolah dasar dengan menggunakan instrumen pengumpulan data berupa kuesioner. Data sekunder tersebut meliputi data umum yang meliputi karakteristik penjaja PJAS (pendidikan terakhir, jenis PJAS yang dijual, sarana penjualan, dan keikutsertaan dalam penyuluhan keamanan pangan); pengetahuan gizi dan keamanan pangan penjaja PJAS; serta praktik penjaja PJAS meliputi higiene penjual atau penyaji makanan atau minuman, penanganan dan penyimpanan makanan atau minuman, sarana dan fasilitas, pengendalian hama dan sanitasi tempat serta peralatan.

\section{Pengolahan dan Analisis Data}

Pengolahan data sekunder meliputi coding dan cleaning data kemudian data ditabulasi dan dianalisis secara statistik dengan program Microsoft Excell 2007 dan SPSS 17.0 for Windows. Data pengetahuan dan praktik gizi dan keamanan pangan penjaja PJAS dikuantifikasikan berdasarkan skor. Pengetahuan dan praktik gizi dan keamanan pangan dikategorikan kurang jika skor $<60 \%$, sedang jika skor $60-80 \%$, dan baik jika skor $>80 \%$ (Khomsan, 2000). Uji statistik yang digunakan yaitu uji t sampel bebas dan uji One-way Anova untuk mengetahui perbedaan rata-rata skor pengetahuan serta praktik gizi dan keamanan pangan, serta uji korelasi Spearman dan Pearson untuk mengetahui hubungan berbagai variabel.

\section{HASIL DAN PEMBAHASAN}

\section{Karakteristik Contoh}

Sebagian besar contoh berpendidikan SD (46.3\%) sedangkan hanya $7.4 \%$ contoh berpendidikan PT (Diploma/S1). Tingkat pendidikan pengelola kantin cenderung lebih baik daripada penjaja luar. Tingkat pendidikan contoh di Sukabumi juga cenderung lebih baik dibandingkan dengan contoh di Jakarta.

Bagian terbesar contoh (31.5\%) menggunakan gerobak dorong sebagai sarana penjualan PJAS sedangkan sebanyak $27.8 \%$ dan $24.1 \%$ contoh menggunakan meja dan warung. Sebanyak $63.9 \%$ contoh menjual makanan sepinggan, $61.1 \%$ contoh menjual makanan ringan, dan $52.8 \%$ contoh menjual minuman.

Sebanyak $62.0 \%$ contoh tidak pernah mengikuti suatu penyuluhan keamanan pangan. Penjaja luar (73.8\%) lebih banyak yang tidak pernah mengikuti penyuluhan keamanan pangan dibandingkan dengan pengelola kantin (44.2\%). Sebanyak 44.8\% contoh di Sukabumi pernah mengikuti penyuluhan keamanan pangan sedangkan hanya $31.6 \%$ contoh di Jakarta yang sudah pernah mengikuti penyuluhan keamanan pangan.

\section{Pengetahuan Gizi dan Keamanan Pangan Contoh}

Sebaran contoh berdasarkan jawaban yang benar pada pertanyaan pengetahuan terkait gizi dan keamanan pangan disajikan pada Tabel 1. Berdasarkan Tabel 1, sebanyak $89.8 \%$ contoh dapat menjawab benar mengenai 4 sehat 5 sempurna sedangkan hanya $34.3 \%$ contoh yang dapat menjawab benar mengenai de- 
finisi pangan jajanan. Pada pertanyaan mengenai pengetahuan terkait keamanan pangan, sebanyak $97.2 \%$ contoh dapat menjawab dengan benar pertanyaan mengenai kebiasaan cuci tangan yang baik. Namun, hanya $39.8 \%$ contoh yang dapat menjawab dengan benar pertanyaan mengenai jenis pangan jajanan yang sering menyebabkan sakit.

Sebaran tingkat pengetahuan gizi dan keamanan contoh berdasarkan kelompok penjaja dan wilayah disajikan pada Tabel 2. Berdasarkan Tabel 2, bagian terbesar contoh memiliki pengetahuan gizi dan keamanan pangan berkategori sedang dengan persentase sebesar $48.1 \%$.

Rata-rata skor pengetahuan gizi dan keamanan pangan pengelola kantin dan contoh di Sukabumi lebih baik daripada penjaja luar dan contoh di Jakarta. Berdasarkan uji t, terdapat perbedaan rata-rata skor pengetahuan gizi dan keamanan pangan yang nyata $(\mathrm{p}<0.05)$ antara penjaja luar dengan pengelola kantin. Hal tersebut diduga karena tingkat pendidikan pengelola kantin yang lebih baik daripada penjaja luar.

Berdasarkan wilayah, perbedaan ratarata skor pengetahuan gizi dan keamanan pangan tidak berbeda nyata $(p>0.05)$. Hal tersebut diduga karena rata-rata skor pengetahuan gizi dan keamanan pangan yang tidak terlalu berbeda jauh. Walaupun contoh di Sukabumi memiliki tingkat pendidikan dan keikutsertaan dalam penyuluhan yang lebih baik daripada contoh di Jakarta, tetapi tidak berbeda jauh diantara keduanya. Salah satu sumber pengetahuan adalah informasi yang diperoleh seseorang. Diduga, akses informasi contoh di Sukabumi maupun Jakarta tidak berbeda jauh sehingga pengetahuan yang dimilikinya pun tidak berbeda nyata. Sebaran tingkat pengetahuan gizi dan keamanan pangan berdasarkan karakteristik contoh disajikan pada Tabel 3.

Tabel 1. Sebaran Contoh berdasarkan Jawaban Benar pada Pertanyaan Pengetahuan terkait Gizi dan Keamanan Pangan

\begin{tabular}{|c|c|c|c|c|c|c|c|}
\hline & \multirow{2}{*}{ Pengetahuan Gizi dan Keamanan Pangan } & \multicolumn{2}{|c|}{$\begin{array}{c}\text { Sukabumi } \\
(n=29)\end{array}$} & \multicolumn{2}{|c|}{$\begin{array}{c}\text { Jakarta } \\
(\mathrm{n}=79)\end{array}$} & \multicolumn{2}{|c|}{$\begin{array}{c}\text { total } \\
(n=108)\end{array}$} \\
\hline & & $\mathrm{n}$ & $\%$ & $\mathrm{n}$ & $\%$ & $\mathrm{n}$ & $\%$ \\
\hline \multicolumn{8}{|c|}{ Pengetahuan gizi } \\
\hline 1 & Pangan yang bergizi & 26 & 89.7 & 58 & 73.4 & 84 & 77.8 \\
\hline 2 & 4 sehat 5 sempurna & 27 & 93.1 & 70 & 88.6 & 97 & 89.8 \\
\hline 3 & Kandungan makanan penghasil tenaga & 19 & 65.5 & 51 & 64.6 & 70 & 64.8 \\
\hline 4 & Jenis makanan penghasil tenaga & 24 & 82.8 & 64 & 81.0 & 88 & 81.5 \\
\hline 5 & Kandungan sayur dan buah & 23 & 79.3 & 53 & 67.1 & 76 & 70.4 \\
\hline 6 & Definisi pangan jajanan & 13 & 44.8 & 24 & 30.4 & 37 & 34.3 \\
\hline \multicolumn{8}{|c|}{ Pengetahuan keamanan pangan } \\
\hline 1 & Akibat mengkonsumsi pangan jajanan tidak bersih dan sehat & 28 & 96.6 & 72 & 91.1 & 100 & 92.6 \\
\hline 2 & Arti dari ditemukan sehelai rambut pada es cendol & 19 & 65.5 & 56 & 70.9 & 75 & 69.4 \\
\hline 3 & Kebiasaan cuci tangan yang baik & 29 & 100.0 & 76 & 96.2 & 105 & 97.2 \\
\hline 4 & $\begin{array}{l}\text { Zat yang ditambahkan dalam es jika es sirup terasa manis tetapi } \\
\text { agak pahit sesaat setelah ditelan }\end{array}$ & 24 & 82.8 & 61 & 77.2 & 85 & 78.7 \\
\hline 5 & $\begin{array}{l}\text { Bahan tambahan yang diijinkan digunakan untuk } \\
\text { mengolah/mengawetkan pangan }\end{array}$ & 17 & 58.6 & 38 & 48.1 & 55 & 50.9 \\
\hline 6 & Akibat dari es batu yang dibuat dari air mentah & 18 & 62.1 & 37 & 46.8 & 55 & 50.9 \\
\hline 7 & Pangan jajanan yang sering menyebabkan sakit & 12 & 41.4 & 31 & 39.2 & 43 & 39.8 \\
\hline 8 & Contoh bahan bukan BTP & 13 & 44.8 & 32 & 40.5 & 45 & 41.7 \\
\hline
\end{tabular}

Tabel 2. Sebaran Tingkat Pengetahuan Gizi dan Keamanan Contoh berdasarkan Kelompok Penjaja dan Wilayah

\begin{tabular}{|c|c|c|c|c|c|c|c|c|c|c|}
\hline \multirow{3}{*}{ Kategori Pengetahuan } & \multicolumn{4}{|c|}{ kelompok penjaja } & \multicolumn{4}{|c|}{ wilayah } & \multirow{2}{*}{\multicolumn{2}{|c|}{$\begin{array}{c}\text { Total } \\
(n=108)\end{array}$}} \\
\hline & \multicolumn{2}{|c|}{ penjaja luar } & \multicolumn{2}{|c|}{ pengelola kantin } & \multicolumn{2}{|c|}{ Sukabumi } & \multicolumn{2}{|c|}{ Jakarta } & & \\
\hline & $\mathrm{n}$ & $\%$ & $\mathrm{n}$ & $\%$ & $\mathrm{n}$ & $\%$ & $\mathrm{n}$ & $\%$ & $\mathrm{n}$ & $\%$ \\
\hline kurang & 25 & 38.5 & 9 & 20.9 & 4 & 13.8 & 30 & 38.0 & 34 & 31.5 \\
\hline sedang & 33 & 50.8 & 19 & 44.2 & 19 & 65.5 & 33 & 41.8 & 52 & 48.1 \\
\hline Baik & 7 & 10.8 & 15 & 34.9 & 6 & 20.7 & 16 & 20.3 & 22 & 20.4 \\
\hline Total & 65 & 100.0 & 43 & 100.0 & 29 & 100.0 & 79 & 100.0 & 108 & 100.0 \\
\hline \multirow[t]{2}{*}{ Rata-rata } & \multicolumn{2}{|c|}{63.6} & \multicolumn{2}{|c|}{72.4} & \multicolumn{2}{|c|}{71.9} & \multicolumn{2}{|c|}{65.4} & \multicolumn{2}{|c|}{67.1} \\
\hline & \multicolumn{4}{|c|}{$p=0.004$} & \multicolumn{4}{|c|}{$p=0.056$} & & \\
\hline
\end{tabular}


Rata-rata skor pengetahuan gizi dan keamanan pangan contoh dengan tingkat pendidikan PT (Diploma/S1) paling baik dibandingkan contoh dengan tingkat pendidikan yang lebih rendah. Seseorang dengan tingkat pendidikan yang lebih tinggi akan lebih baik dalam menerima, memproses, menginterpretasikan, dan menggunakan informasi (Contento, 2007). Informasi tersebut dapat mempengaruhi pengetahuan yang diperoleh seseorang (WHO, 2000).

Berdasarkan keikutsertaan penyuluhan keamanan pangan, contoh yang pernah mengikuti suatu penyuluhan keamanan pangan memiliki rata-rata skor pengetahuan gizi dan keamanan pangan yang lebih baik dibandingkan dengan contoh yang tidak pernah mengikuti maupun tidak tahu mengenai penyuluhan keamanan pangan. Penyuluhan merupakan salah satu bentuk pendidikan non-formal yang dapat mempengaruhi tingkat pengetahuan seseorang.

Berdasarkan uji one-way Anova terdapat perbedaan rata-rata skor pengetahuan gizi dan keamanan pangan yang nyata $(p<0.05)$ berdasarkan tingkat pendidikan. Berdasarkan keikutsertaan penyuluhan keamanan pangan, perbedaan rata-rata skor pengetahuan gizi dan keamanan pangan juga berbeda nyata $(p<0.05)$.

\section{Praktik Gizi dan Keamanan Pangan Contoh}

Pada analisis ini, praktik gizi contoh dapat dilihat dari profil PJAS yang dijual oleh contoh. Berdasarkan hasil analisis profil PJAS, buah-buahan hanya tersedia sebanyak $2 \%$ di Sukabumi dan 3\% di Jakarta dari keseluruhan PJAS yang dijual. Hal tersebut menunjukkan jenis PJAS yang dijual oleh penjaja belum beragam.

Berdasarkan Tabel 4, lebih dari $90 \%$ contoh tidak mempunyai luka terbuka. Namun, praktik higiene contoh masih sangat kurang dalam hal mencuci tangan sebelum dan setelah melayani pembeli. Contoh juga masih banyak yang memegang uang selama mengolah dan menyajikan makanan. Pada praktik penanganan dan penyimpanan pangan, hampir $90 \%$ contoh tidak terdapat bahan-bahan beracun di area penjualannya. Namun, hanya $11.1 \%$ contoh yang menggunakan Bahan Tambahan Pangan (BTP) sesuai dengan petunjuk dan ketentuan yang berlaku.

Tabel 5 menunjukkan bahwa praktik sarana dan fasilitas masih kurang dalam hal tersedia tempat pencucian peralatan dengan suplai air mengalir, tempat cuci tangan, dan lap peralatan. Hal tersebut menjelaskan mengapa sebagian besar contoh tidak mencuci tangan sebelum dan setelah melayani pembeli. Sarana dan fasilitas merupakan faktor pemungkin terbentuknya atau berubahnya perilaku seseorang (Notoatmodjo 2007). Bagian terbesar contoh (66.7\%) telah menggunakan tempat/wadah yang bersih untuk menjual PJAS. Pada praktik pengendalian hama, sanitasi tempat dan peralatan menunjukkan hanya 9.3\% contoh yang memiliki lap bersih dan kering untuk mengeringkan peralatan.

Sebaran praktik keamanan pangan contoh berdasarkan kelompok penjaja dan wilayah disajikan pada Tabel 6. Sebagian besar contoh dengan persentase sebesar $74.1 \%$ memiliki praktik keamanan pangan berkategori kurang. Hanya 4.6\% contoh yang berkategori baik.

Rata-rata skor praktik higiene contoh, penanganan dan penyimpanan pangan, sarana dan fasilitas, serta pengendalian hama, sanitasi tempat dan peralatan pengelola kantin lebih baik daripada penjaja luar. Sama halnya dengan contoh berdasarkan kelompok penjaja, praktik higiene contoh, penanganan dan penyimpanan pangan, serta pengendalian hama, sanitasi tempat dan peralatan contoh di Sukabumi lebih baik daripada contoh di Jakarta. Namun, praktik sarana dan fasilitas contoh di Jakarta lebih baik daripada di Sukabumi.

Tabel 3. Sebaran Tingkat Pengetahuan Gizi dan Keamanan Pangan berdasarkan Karakteristik Contoh

\begin{tabular}{|c|c|c|c|c|c|c|c|c|c|c|c|c|c|c|c|c|}
\hline \multirow{3}{*}{ kategori pengetahuan } & \multicolumn{8}{|c|}{ tingkat pendidikan } & \multicolumn{6}{|c|}{ keikutsertaan penyuluhan } & \multirow{2}{*}{\multicolumn{2}{|c|}{ Total $(n=108)$}} \\
\hline & \multicolumn{2}{|c|}{ SD } & \multicolumn{2}{|c|}{ SMP } & \multicolumn{2}{|c|}{ SMA } & \multicolumn{2}{|c|}{ PT } & \multicolumn{2}{|c|}{ pernah } & \multicolumn{2}{|c|}{ tidak pernah } & \multicolumn{2}{|c|}{ tidak tahu } & & \\
\hline & $\mathrm{n}$ & $\%$ & $\mathrm{n}$ & $\%$ & $\mathrm{n}$ & $\%$ & $\mathrm{n}$ & $\%$ & $\mathrm{n}$ & $\%$ & $n$ & $\%$ & $\mathrm{n}$ & $\%$ & $\mathrm{n}$ & $\%$ \\
\hline Kurang & 22 & 44.0 & 11 & 39.3 & 1 & 4.5 & 0 & 0.0 & 8 & 21.1 & 23 & 34.3 & 3 & 100.0 & 34 & 31.5 \\
\hline Sedang & 21 & 42.0 & 14 & 50.0 & 13 & 59.1 & 4 & 50.0 & 18 & 47.4 & 34 & 50.7 & 0 & 0.0 & 52 & 48.1 \\
\hline Baik & 7 & 14.0 & 3 & 10.7 & 8 & 36.4 & 4 & 50.0 & 12 & 31.6 & 10 & 14.9 & 0 & 0.0 & 22 & 20.4 \\
\hline Total & 50 & 100.0 & 28 & 100.0 & 22 & 100.0 & 8 & 100.0 & 38 & 100.0 & 67 & 100.0 & 3 & 100.0 & 108 & 100.0 \\
\hline \multirow[t]{2}{*}{ rata-rata } & \multicolumn{2}{|c|}{63.3} & \multicolumn{2}{|c|}{64.0} & \multicolumn{2}{|c|}{75.6} & \multicolumn{2}{|c|}{78.6} & \multicolumn{2}{|c|}{72.6} & \multicolumn{2}{|c|}{65.7} & \multicolumn{2}{|c|}{31.0} & \multicolumn{2}{|c|}{67.1} \\
\hline & & & \multicolumn{4}{|c|}{$p=0.002$} & & & & & \multicolumn{2}{|c|}{$p=0.000$} & & & & \\
\hline
\end{tabular}


Tabel 4. Sebaran Contoh berdasarkan Praktik Higiene serta Penanganan dan Penyimpanan Pangan yang Benar

\begin{tabular}{|c|c|c|c|c|c|c|c|}
\hline \multirow[t]{2}{*}{ No } & \multirow[t]{2}{*}{ Praktik Keamanan Pangan } & \multicolumn{2}{|c|}{$\begin{array}{l}\text { Sukabumi } \\
(n=29)\end{array}$} & \multicolumn{2}{|c|}{$\begin{array}{c}\text { Jakarta } \\
(n=79)\end{array}$} & \multicolumn{2}{|c|}{$\begin{array}{c}\text { Total } \\
(n=108)\end{array}$} \\
\hline & & $n$ & $\%$ & $n$ & $\%$ & $\mathrm{~N}$ & $\%$ \\
\hline & Higiene & & & & & & \\
\hline 1 & Contoh menangani makanan/minuman dengan bersih dan sehat & 28 & 96.6 & 65 & 82.3 & 93 & 86.1 \\
\hline 2 & Contoh menggunakan baju yang bersih & 29 & 100.0 & 67 & 84.8 & 96 & 88.9 \\
\hline 3 & Contoh tidak mempunyai luka yang terbuka & 29 & 100.0 & 70 & 88.6 & 99 & 91.7 \\
\hline 4 & $\begin{array}{l}\text { Contoh tidak memegang (menerima/mengembalikan) uang selama } \\
\text { mengolah/menyajikan pangan }\end{array}$ & 2 & 6.9 & 13 & 16.5 & 15 & 13.9 \\
\hline 5 & $\begin{array}{l}\text { Contoh tidak menyentuh pangan langsung dengan tangan saat } \\
\text { menyajikan melainkan menggunakan sendok atau alat lain }\end{array}$ & 7 & 24.1 & 39 & 49.4 & 46 & 42.6 \\
\hline 6 & $\begin{array}{l}\text { Contoh tidak makan dan minum atau merokok, selama melayani } \\
\text { pembeli }\end{array}$ & 25 & 86.2 & 69 & 87.3 & 94 & 87.0 \\
\hline 7 & $\begin{array}{l}\text { Contoh tidak menggaruk-garuk badan dan bersin atau batuk selama } \\
\text { melayani pembeli }\end{array}$ & 26 & 89.7 & 69 & 87.3 & 95 & 88.0 \\
\hline 8 & Sebelum melayani pembeli, contoh mencuci tangan & 1 & 3.4 & 2 & 2.5 & 3 & 2.8 \\
\hline 9 & Setelah melayani pembeli, contoh mencuci tangan & 3 & 10.3 & 2 & 2.5 & 5 & 4.6 \\
\hline & Penanganan dan Penyimpanan Makanan/Minuman & & & & & & \\
\hline 1 & $\begin{array}{l}\text { Bahan minuman yang cepat rusak seperti susu atau santan disimpan di } \\
\text { dalam lemari es/kulkas atau termos es }\end{array}$ & 4 & 13.8 & 20 & 25.3 & 24 & 22.2 \\
\hline 2 & Bahan-bahan kering seperti gula dipisahkan dari bahan-bahan basah & 24 & 82.8 & 23 & 29.1 & 47 & 43.5 \\
\hline 3 & $\begin{array}{l}\text { Tidak terdapat bahan-bahan beracun (misalnya : obat nyamuk cair) di } \\
\text { area penjualan }\end{array}$ & 29 & 100.0 & 68 & 86.1 & 97 & 89.8 \\
\hline 4 & $\begin{array}{l}\text { Makanan/minuman disajikan atau dikemas dalam pengemas yang } \\
\text { bersih }\end{array}$ & 24 & 82.8 & 65 & 82.3 & 89 & 82.4 \\
\hline 5 & Plastik bekas tidak digunakan sebagai kemasan makanan/minuman & 25 & 86.2 & 68 & 86.1 & 93 & 86.1 \\
\hline 6 & Makanan/minuman yang dijual selalu ditutup & 12 & 41.4 & 44 & 55.7 & 56 & 51.9 \\
\hline 7 & $\begin{array}{l}\text { Bahan tambahan kimia atau alami yang ditambahkan ke dalam } \\
\text { minuman adalah bahan yang diijinkan }\end{array}$ & 9 & 31.0 & 26 & 32.9 & 35 & 32.4 \\
\hline 8 & $\begin{array}{l}\text { Penggunaan bahan tambahan kimia atau alami yang ditambahkan ke } \\
\text { dalam minuman sesuai dengan petunjuk dan ketentuan yang berlaku }\end{array}$ & 6 & 20.7 & 6 & 7.6 & 12 & 11.1 \\
\hline
\end{tabular}

Tabel 5. Sebaran Contoh berdasarkan Praktik Sarana dan Fasilitas serta Pengendalian Hama, Sanitasi Tempat dan Peralatan yang Benar

\begin{tabular}{|c|c|c|c|c|c|c|c|}
\hline \multirow[t]{2}{*}{ No } & \multirow[t]{2}{*}{ praktik keamanan pangan } & \multicolumn{2}{|c|}{$\begin{array}{l}\text { sukabumi } \\
(\mathrm{n}=29)\end{array}$} & \multicolumn{2}{|c|}{$\begin{array}{l}\text { jakarta } \\
(\mathrm{n}=79)\end{array}$} & \multicolumn{2}{|c|}{$\begin{array}{c}\text { total } \\
(n=108)\end{array}$} \\
\hline & & $\mathrm{n}$ & $\%$ & $\mathrm{n}$ & $\%$ & $\mathrm{n}$ & $\%$ \\
\hline & Sarana dan Fasilitas & & & & & & \\
\hline 1 & $\begin{array}{l}\text { Tempat (wadah) untuk menjual makanan/minuman dalam keadaan } \\
\text { bersih }\end{array}$ & 28 & 96.6 & 44 & 55.7 & 72 & 66.7 \\
\hline 2 & Tersedia tempat cuci tangan & 3 & 10.3 & 35 & 44.3 & 38 & 35.2 \\
\hline 3 & Tersedia lap tangan & 21 & 72.4 & 40 & 50.6 & 61 & 56.5 \\
\hline 4 & Tersedia lap peralatan & 5 & 17.2 & 33 & 41.8 & 38 & 35.2 \\
\hline 5 & Tersedia tempat sampah & 22 & 75.9 & 44 & 55.7 & 66 & 61.1 \\
\hline 6 & Tersedia tempat pencucian peralatan dengan suplai air mengalir & 2 & 6.9 & 32 & 40.5 & 34 & 31.5 \\
\hline & Pengendalian Hama, Sanitasi Tempat dan Peralatan & & & & & & \\
\hline 1 & $\begin{array}{l}\text { Tidak ada binatang pengerat, serangga dan binatang lainnya di } \\
\text { tempat penjualan makanan/minuman }\end{array}$ & 25 & 86.2 & 55 & 69.6 & 80 & 74.1 \\
\hline 2 & Ada upaya untuk mencegah masuknya hama (kecoak, semut, dll) & 26 & 89.7 & 21 & 26.6 & 47 & 43.5 \\
\hline 3 & Tidak terdapat bahan pangan yang berserakan & 22 & 75.9 & 59 & 74.7 & 81 & 75.0 \\
\hline 4 & Tidak terdapat air tergenang di sekitar tempat penjualan & 28 & 96.6 & 59 & 74.7 & 87 & 80.6 \\
\hline 5 & Sampah dibuang secara teratur & 13 & 44.8 & 30 & 38.0 & 43 & 39.8 \\
\hline 6 & $\begin{array}{l}\text { Pencucian peralatan dengan menggunakan air mengalir/selalu } \\
\text { diganti }\end{array}$ & 8 & 27.6 & 36 & 45.6 & 44 & 40.7 \\
\hline 7 & $\begin{array}{l}\text { Tidak terdapat tumpukan sampah atau kotoran di dekat tempat } \\
\text { berjualan }\end{array}$ & 26 & 89.7 & 54 & 68.4 & 80 & 74.1 \\
\hline 8 & Tidak berdekatan dengan saluran pembuangan air & 25 & 86.2 & 33 & 41.8 & 58 & 53.7 \\
\hline 9 & Tempat penjualan (gerobak, meja, dll) terawat dan bersih & 23 & 79.3 & 39 & 49.4 & 62 & 57.4 \\
\hline 10 & Deterjen disimpan terpisah dan diberi label & 11 & 37.9 & 14 & 17.7 & 25 & 23.1 \\
\hline 11 & Peralatan tersimpan dalam keadaan bersih dan kering & 9 & 31.0 & 58 & 73.4 & 67 & 62.0 \\
\hline 12 & Jika peralatan dikeringkan dengan lap, tersedia lap bersih dan kering & 8 & 27.6 & 2 & 2.5 & 10 & 9.3 \\
\hline 13 & $\begin{array}{l}\text { Gelas/mangkok/sendok selalu dikeringkan dengan lap yang bersih } \\
\text { sebelum digunakan untuk menyajikan minuman }\end{array}$ & 7 & 24.1 & 7 & 8.9 & 14 & 13.0 \\
\hline
\end{tabular}


Tabel 6. Sebaran Praktik Keamanan Pangan Contoh berdasarkan Kelompok Penjaja dan Wilayah

\begin{tabular}{|c|c|c|c|c|c|c|c|c|c|c|}
\hline \multirow{3}{*}{$\begin{array}{c}\text { kategori } \\
\text { praktik }\end{array}$} & \multicolumn{4}{|c|}{ kelompok penjaja } & \multicolumn{4}{|c|}{ wilayah } & \multirow{2}{*}{\multicolumn{2}{|c|}{$\begin{array}{c}\text { Total } \\
(n=108)\end{array}$}} \\
\hline & \multicolumn{2}{|c|}{ penjaja luar } & \multicolumn{2}{|c|}{ pengelola kantin } & \multicolumn{2}{|c|}{ sukabumi } & \multicolumn{2}{|c|}{ jakarta } & & \\
\hline & $\mathrm{n}$ & $\%$ & $\mathrm{n}$ & $\%$ & $\mathrm{n}$ & $\%$ & $\mathrm{n}$ & $\%$ & $\mathrm{n}$ & $\%$ \\
\hline \multicolumn{11}{|l|}{ Higiene } \\
\hline Kurang & 41 & 63.1 & 29 & 67.4 & 21 & 72.4 & 49 & 62.0 & 70 & 64.8 \\
\hline Sedang & 23 & 35.4 & 12 & 27.9 & 7 & 24.1 & 28 & 35.4 & 35 & 32.4 \\
\hline Baik & 1 & 1.5 & 2 & 4.7 & 1 & 3.4 & 2 & 2.5 & 3 & 2.8 \\
\hline Total & 65 & 100.0 & 43 & 100.0 & 29 & 100.0 & 79 & 100.0 & 108 & 100.0 \\
\hline Rata-rata & \multicolumn{2}{|c|}{55.9} & \multicolumn{2}{|c|}{56.6} & \multicolumn{2}{|c|}{57.5} & \multicolumn{2}{|c|}{55.7} & \multicolumn{2}{|c|}{56.2} \\
\hline \multicolumn{11}{|c|}{ Penanganan dan Penyimpanan Pangan } \\
\hline Kurang & 35 & 53.8 & 26 & 60.5 & 15 & 51.7 & 46 & 58.2 & 61 & 56.5 \\
\hline Sedang & 28 & 43.1 & 14 & 32.6 & 11 & 37.9 & 31 & 39.2 & 42 & 38.9 \\
\hline Baik & 2 & 3.1 & 3 & 7.0 & 3 & 10.3 & 2 & 2.5 & 5 & 4.6 \\
\hline Total & 65 & 100.0 & 43 & 100.0 & 29 & 100.0 & 79 & 100.0 & 108 & 100.0 \\
\hline Rata-rata & \multicolumn{2}{|c|}{51.7} & \multicolumn{2}{|c|}{53.5} & \multicolumn{2}{|c|}{57.3} & \multicolumn{2}{|c|}{50.6} & \multicolumn{2}{|c|}{52.4} \\
\hline \multicolumn{11}{|c|}{ Sarana dan Fasilitas } \\
\hline Kurang & 51 & 78.5 & 23 & 53.5 & 23 & 79.3 & 51 & 64.6 & 74 & 68.5 \\
\hline Sedang & 4 & 6.2 & 5 & 11.6 & 3 & 10.3 & 6 & 7.6 & 9 & 8.3 \\
\hline Baik & 10 & 15.4 & 15 & 34.9 & 3 & 10.3 & 22 & 27.8 & 25 & 23.1 \\
\hline Total & 65 & 100.0 & 43 & 100.0 & 29 & 100.0 & 79 & 100.0 & 108 & 100.0 \\
\hline Rata-rata & \multicolumn{2}{|c|}{41.8} & \multicolumn{2}{|c|}{56.6} & \multicolumn{2}{|c|}{46.6} & \multicolumn{2}{|c|}{48.1} & \multicolumn{2}{|c|}{47.7} \\
\hline \multicolumn{11}{|c|}{ Pengendalian Hama, Sanitasi Tempat dan Peralatan } \\
\hline Kurang & 54 & 83.1 & 20 & 46.5 & 13 & 44.8 & 61 & 77.2 & 74 & 68.5 \\
\hline Sedang & 10 & 15.4 & 17 & 39.5 & 12 & 41.4 & 15 & 19.0 & 27 & 25.0 \\
\hline Baik & 1 & 1.5 & 6 & 14.0 & 4 & 13.8 & 3 & 3.8 & 7 & 6.5 \\
\hline Total & 65 & 100.0 & 43 & 100.0 & 29 & 100.0 & 79 & 100.0 & 108 & 100.0 \\
\hline Rata-rata & & & & & & .3 & & 5.5 & & \\
\hline Praktik keam & anga & & & & & & & & & \\
\hline Kurang & 55 & 84.6 & 25 & 58.1 & 19 & 65.5 & 61 & 77.2 & 80 & 74.1 \\
\hline Sedang & 9 & 13.8 & 14 & 32.6 & 7 & 24.1 & 16 & 20.3 & 23 & 21.3 \\
\hline Baik & 1 & 1.5 & 4 & 9.3 & 3 & 10.3 & 2 & 2.5 & 5 & 4.6 \\
\hline Total & 65 & 100.0 & 43 & 100.0 & 29 & 100.0 & 79 & 100.0 & 108 & 100.0 \\
\hline rata-rata & & & & & & .0 & & 9.6 & & \\
\hline & & & & & & & 028 & & & \\
\hline
\end{tabular}

Praktik keamanan pangan pengelola kantin maupun contoh di Sukabumi yang lebih baik diduga disebabkan tingkat pengetahuan gizi dan keamanan pangan yang lebih baik dibandingkan dengan penjaja luar maupun contoh di Jakarta. Selain itu, tingkat pendidikan pengelola kantin dan contoh di Sukabumi lebih baik dibandingkan dengan penjaja luar dan contoh di Jakarta.

Berdasarkan hasil uji $t$, rata-rata skor praktik keamanan pangan pengelola kantin dengan penjaja luar menunjukkan perbedaan yang nyata $(p<0.05)$ dengan rata-rata skor pengelola kantin yang lebih baik dibandingkan dengan penjaja luar. Begitu pula halnya dengan rata-rata skor praktik keamanan pangan contoh di Sukabumi berbeda nyata dengan contoh di Jakarta $(p<0.05)$. Rata-rata skor praktik keamanan pangan contoh di Sukabumi lebih baik daripada contoh di Jakarta.
Menurut Notoatmodjo (2007), dalam proses pembentukan dan atau perubahan, perilaku dipengaruhi oleh beberapa faktor yang berasal dari dalam dan luar individu itu sendiri. Selain pengetahuan dan persepsi sebagai faktor internal yang mempengaruhi terbentuknya perilaku, terdapat pula faktor eksternal meliputi lingkungan sekitar, baik fisik maupun non-fisik seperti: iklim, manusia, sosial-ekonomi, kebudayaan, dan sebagainya. Hal ini mendukung hasil analisis yang menyatakan terdapat perbedaan praktik keamanan pangan yang nyata diantara Sukabumi dan Jakarta. Sukabumi sebagai daerah pedesaan dan Jakarta sebagai kota metropolitan memiliki keadaan iklim, manusia, sosial-ekonomi, dan kebudayaan yang berbeda. Hal tersebut dapat menjadi faktor eksternal yang cukup kuat untuk mempengaruhi proses pembentukan maupun perubahan perilaku.

Sebaran tingkat praktik keamanan pangan berdasarkan karakteristik contoh disaji- 
kan pada Tabel 7. Contoh yang berpendidikan PT (Diploma/S1) memiliki rata-rata skor praktik higiene contoh serta penanganan dan penyimpanan pangan yang lebih baik dibandingkan contoh dengan tingkat pendidikan yang lebih rendah. Praktik sarana dan fasilitas, pengendalian hama, sanitasi tempat dan peralatan serta praktik keamanan pangan total contoh yang berpendidikan SMA lebih baik dibandingkan contoh dengan kategori tingkat pendidikan lainnya.

Praktik penanganan dan penyimpanan pangan, sarana dan fasilitas, pengendalian hama, sanitasi tempat dan peralatan, serta praktik keamanan pangan total contoh yang pernah mengikuti penyuluhan keamanan pangan lebih baik daripada contoh yang tidak pernah mengikuti ataupun tidak tahu mengenai penyuluhan keamanan pangan. Namun, praktik higiene contoh yang tidak pernah mengikuti penyuluhan keamanan pangan lebih baik daripada contoh yang pernah mengikuti penyuluhan keamanan pangan. Hal tersebut diduga disebabkan oleh pengalaman mengenai praktik higiene contoh yang tidak pernah mengikuti penyuluhan keamanan pangan lebih banyak daripada yang pernah mengikuti penyuluhan keamanan pangan. Pengalaman dapat secara langsung mempengaruhi perilaku individu (Institute of Medicine National Research Council, 1998).

Berdasarkan hasil uji one-way Anova, rata-rata skor praktik keamanan pangan contoh berdasarkan tingkat pendidikan menunjukkan perbedaan nyata $(p<0.05)$. Rata-rata skor praktik keamanan pangan contoh berdasarkan keikutsertaan dalam penyuluhan keamanan pangan tidak berbeda nyata $(p>0.05)$.

Tabel 7. Sebaran Praktik Keamanan Pangan berdasarkan Karakteristik Contoh

\begin{tabular}{|c|c|c|c|c|c|c|c|c|c|c|c|c|c|c|c|c|}
\hline \multirow{3}{*}{$\begin{array}{c}\text { kategori } \\
\text { praktik }\end{array}$} & \multicolumn{8}{|c|}{ tingkat pendidikan } & \multicolumn{6}{|c|}{ keikutsertaan penyuluhan } & \multirow{2}{*}{\multicolumn{2}{|c|}{$\begin{array}{c}\text { Total } \\
(n=108)\end{array}$}} \\
\hline & \multicolumn{2}{|r|}{ SD } & \multicolumn{2}{|c|}{ SMP } & \multicolumn{2}{|c|}{ SMA } & \multicolumn{2}{|r|}{ PT } & \multicolumn{2}{|c|}{ pernah } & \multicolumn{2}{|c|}{ tidak pernah } & \multicolumn{2}{|c|}{ tidak tahu } & & \\
\hline & $\mathrm{n}$ & $\%$ & $\mathrm{n}$ & $\%$ & $\mathrm{n}$ & $\%$ & $\mathrm{n}$ & $\%$ & $\mathrm{n}$ & $\%$ & $\mathrm{n}$ & $\%$ & $\mathrm{n}$ & $\%$ & $\mathrm{n}$ & $\%$ \\
\hline \multicolumn{17}{|l|}{ Higiene } \\
\hline Kurang & 34 & 68.0 & 17 & 60.7 & 13 & 59.1 & 6 & 75.0 & 29 & 76.3 & 39 & 58.2 & 2 & 66.7 & 70 & 64.8 \\
\hline Sedang & 16 & 32.0 & 11 & 39.3 & 7 & 31.8 & 1 & 12.5 & 8 & 21.1 & 26 & 38.8 & 1 & 33.3 & 35 & 32.4 \\
\hline Baik & 0 & 0.0 & 0 & 0.0 & 2 & 9.1 & 1 & 12.5 & 1 & 2.6 & 2 & 3.0 & 0 & 0.0 & 3 & 2.8 \\
\hline Total & 50 & 100.0 & 28 & 100.0 & 22 & 100.0 & 8 & 100.0 & 38 & 100.0 & 67 & 100.0 & 3 & 100.0 & 108 & 100.0 \\
\hline Rata-rata & \multicolumn{2}{|c|}{54.4} & \multicolumn{2}{|r|}{55.2} & \multicolumn{2}{|c|}{59.6} & \multicolumn{2}{|r|}{61.1} & \multicolumn{2}{|c|}{54.4} & \multicolumn{2}{|c|}{57.7} & \multicolumn{2}{|r|}{44.4} & \multicolumn{2}{|c|}{56.2} \\
\hline \multicolumn{17}{|c|}{ Penanganan dan Penyimpanan Pangan } \\
\hline Kurang & 30 & 60.0 & 15 & 53.6 & 11 & 50.0 & 5 & 62.5 & 22 & 57.9 & 37 & 55.2 & 2 & 66.7 & 61 & 56.5 \\
\hline Sedang & 20 & 40.0 & 12 & 42.9 & 8 & 36.4 & 2 & 25.0 & 13 & 34.2 & 28 & 41.8 & 1 & 33.3 & 42 & 38.9 \\
\hline Baik & 0 & 0.0 & 1 & 3.6 & 3 & 13.6 & 1 & 12.5 & 3 & 7.9 & 2 & 3.0 & 0 & 0.0 & 5 & 4.6 \\
\hline Total & 50 & 100.0 & 28 & 100.0 & 22 & 100.0 & 8 & 100.0 & 38 & 100.0 & 67 & 100.0 & 3 & 100.0 & 108 & 100.0 \\
\hline Rata-rata & \multicolumn{2}{|c|}{50.3} & \multicolumn{2}{|r|}{50.9} & \multicolumn{2}{|c|}{57.4} & & 57.8 & & 53.6 & & .9 & & 50.0 & & 2.4 \\
\hline Sarana dan & 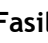 & tas & & & & & & & & & & & & & & \\
\hline Kurang & 36 & 72.0 & 23 & 82.1 & 10 & 45.5 & 5 & 62.5 & 22 & 57.9 & 50 & 74.6 & 2 & 66.7 & 74 & 68.5 \\
\hline Sedang & 6 & 12.0 & 0 & 0.0 & 3 & 13.6 & 0 & 0.0 & 6 & 15.8 & 3 & 4.5 & 0 & 0.0 & 9 & 8.3 \\
\hline Baik & 8 & 16.0 & 5 & 17.9 & 9 & 40.9 & 3 & 37.5 & 10 & 26.3 & 14 & 20.9 & 1 & 33.3 & 25 & 23.1 \\
\hline Total & 50 & 100.0 & 28 & 100.0 & 22 & 100.0 & 8 & 100.0 & 38 & 100.0 & 67 & 100.0 & 3 & 100.0 & 108 & 100.0 \\
\hline Rata-rata & & 44.3 & & 40.5 & & 62.1 & & 54.2 & & 55.3 & & .0 & & 55.6 & & 7.7 \\
\hline Pengendal & & na, San & & Tempa & ain & Peralata & & & & & & & & & & \\
\hline Kurang & 36 & 72.0 & 22 & 78.6 & 10 & 45.5 & 6 & 75.0 & 25 & 65.8 & 48 & 71.6 & 1 & 33.3 & 74 & 68.5 \\
\hline Sedang & 14 & 28.0 & 5 & 17.9 & 7 & 31.8 & 1 & 12.5 & 9 & 23.7 & 16 & 23.9 & 2 & 66.7 & 27 & 25.0 \\
\hline Baik & 0 & 0.0 & 1 & 3.6 & 5 & 22.7 & 1 & 12.5 & 4 & 10.5 & 3 & 4.5 & 0 & 0.0 & 7 & 6.5 \\
\hline Total & 50 & 100.0 & 28 & 100.0 & 22 & 100.0 & 8 & 100.0 & 38 & 100.0 & 67 & 100.0 & 3 & 100.0 & 108 & 100.0 \\
\hline Rata-rata & & 45.4 & & 48.1 & & 60.1 & & 53.8 & & 53.0 & & .9 & & 48.7 & & 9.7 \\
\hline praktik ke & . & panga & & & & & & & & & & & & & & \\
\hline Kurang & 42 & 84.0 & 22 & 78.6 & 10 & 45.5 & 6 & 75.0 & 25 & 65.8 & 53 & 79.1 & 2 & 66.7 & 80 & 74.1 \\
\hline Sedang & 8 & 16.0 & 6 & 21.4 & 8 & 36.4 & 1 & 12.5 & 11 & 28.9 & 11 & 16.4 & 1 & 33.3 & 23 & 21.3 \\
\hline Baik & 0 & 0.0 & 0 & 0.0 & 4 & 18.2 & 1 & 12.5 & 2 & 5.3 & 3 & 4.5 & 0 & 0.0 & 5 & 4.6 \\
\hline Total & 50 & 100.0 & 28 & 100.0 & 22 & 100.0 & 8 & 100.0 & 38 & 100.0 & 67 & 100.0 & 3 & 100.0 & 108 & 100.0 \\
\hline rata-rata & & 48.6 & & 49.2 & & 59.7 & & 56.6 & & 53.9 & & .4 & & 49.1 & & 1.6 \\
\hline & & & & $\mathrm{p}=0$. & 022 & & & & & & & .530 & & & & \\
\hline
\end{tabular}




\section{Hubungan Tingkat Pendidikan dengan Pengetahuan Gizi dan Keamanan Pangan}

Berdasarkan hasil uji korelasi Spearman, terlihat bahwa terdapat hubungan positif yang nyata antara tingkat pendidikan dengan pengetahuan gizi dan keamanan pangan $(p<0.05)$. Hal ini berarti semakin tinggi tingkat pendidikan contoh, semakin baik tingkat pengetahuan gizi dan keamanan pangan.

Tingkat pendidikan adalah salah satu faktor yang memudahkan seseorang atau masyarakat untuk menyerap informasi (Atmarita \& Fallah, 2004). Hal senada juga dinyatakan oleh Contento (2007) yaitu seseorang dengan tingkat pendidikan yang lebih tinggi akan lebih baik dalam menerima, memproses, menginterpretasikan, dan menggunakan informasi yang diperolehnya.

\section{Hubungan Tingkat Pendidikan dengan Praktik Keamanan Pangan}

Berdasarkan hasil uji korelasi Spearman, hubungan antara tingkat pendidikan dengan praktik keamanan pangan sangat nyata $(\mathrm{p}<0.05)$. Menurut Atmarita dan Fallah (2004), seseorang dengan tingkat pendidikan yang baik akan lebih mudah mengimplementasikan informasi dan pengetahuan yang dimilikinya dalam perilaku serta gaya hidup sehari-hari.

\section{Hubungan Pengetahuan Gizi dan Keamanan Pangan dengan Praktik Keamanan Pangan}

Pengetahuan atau kognitif merupakan domain yang sangat penting untuk terbentuknya tindakan seseorang (overt behaviour) (Notoatmodjo, 2007). Berdasarkan hasil uji korelasi Pearson, hubungan antara pengetahuan gizi dan keamanan pangan dengan praktik keamanan pangan tidak menunjukkan hubungan yang nyata $(p>0.05)$.

Namun, berdasarkan Tabel 10 terdapat kecenderungan semakin baik pengetahuan gizi dan keamanan pangan semakin baik praktik keamanan pangan contoh. Hal tersebut dibuktikan dengan tidak ada contoh yang memiliki pengetahuan gizi dan keamanan pangan berkategori kurang yang praktik keamanan pangannya baik.

Tabel 8. Hubungan antara Tingkat Pendidikan dengan Pengetahuan Gizi dan Keamanan Pangan

\begin{tabular}{|c|c|c|c|c|c|c|c|c|c|c|}
\hline \multirow{3}{*}{$\begin{array}{c}\text { Pengetahuan } \\
\text { Gizi dan } \\
\text { Keamanan Pangan }\end{array}$} & \multicolumn{8}{|c|}{ Tingkat Pendidikan } & \multirow{2}{*}{\multicolumn{2}{|c|}{ Total $(n=108)$}} \\
\hline & \multicolumn{2}{|c|}{ SD } & \multicolumn{2}{|c|}{ SMP } & \multicolumn{2}{|c|}{ SMA } & \multicolumn{2}{|c|}{ PT } & & \\
\hline & $\mathrm{n}$ & $\%$ & $\mathrm{n}$ & $\%$ & $\mathrm{n}$ & $\%$ & $\mathrm{n}$ & $\%$ & $\mathrm{n}$ & $\%$ \\
\hline kurang & 22 & 44.0 & 11 & 39.3 & 1 & 4.5 & 0 & 0.0 & 34 & 31.5 \\
\hline sedang & 21 & 42.0 & 14 & 50.0 & 13 & 59.1 & 4 & 50.0 & 52 & 48.1 \\
\hline baik & 7 & 14.0 & 3 & 10.7 & 8 & 36.4 & 4 & 50.0 & 22 & 20.4 \\
\hline \multirow[t]{2}{*}{ total } & 50 & 100.0 & 28 & 100.0 & 22 & 100.0 & 8 & 100.0 & 108 & 100.0 \\
\hline & & & & & & & & & \multicolumn{2}{|c|}{$p=0.000 ; r=0.360$} \\
\hline
\end{tabular}

Tabel 9. Hubungan antara Tingkat Pendidikan dengan Praktik Keamanan Pangan

\begin{tabular}{|c|c|c|c|c|c|c|c|c|c|c|}
\hline \multirow{3}{*}{$\begin{array}{c}\text { Praktik } \\
\text { Keamanan pangan }\end{array}$} & \multicolumn{8}{|c|}{ Tingkat Pendidikan } & \multirow{2}{*}{\multicolumn{2}{|c|}{ Total $(n=108)$}} \\
\hline & \multicolumn{2}{|c|}{ SD } & \multicolumn{2}{|c|}{ SMP } & \multicolumn{2}{|c|}{ SMA } & \multicolumn{2}{|c|}{ PT } & & \\
\hline & $\mathrm{n}$ & $\%$ & $\mathrm{n}$ & $\%$ & $\mathrm{n}$ & $\%$ & $\mathrm{n}$ & $\%$ & $n$ & $\%$ \\
\hline kurang & 42 & 84.0 & 22 & 78.6 & 10 & 45.5 & 6 & 75.0 & 80 & 74.1 \\
\hline sedang & 8 & 16.0 & 6 & 21.4 & 8 & 36.4 & 1 & 12.5 & 23 & 21.3 \\
\hline baik & 0 & 0.0 & 0 & 0.0 & 4 & 18.2 & 1 & 12.5 & 5 & 4.6 \\
\hline \multirow[t]{2}{*}{ total } & 50 & 100.0 & 28 & 100.0 & 22 & 100.0 & 8 & 100.0 & 108 & 100.0 \\
\hline & & & & & & & & & \multicolumn{2}{|c|}{$p=0.004 ; r=0.27$} \\
\hline
\end{tabular}

Tabel 10. Hubungan antara Pengetahuan Gizi dan Keamanan Pangan dengan Praktik Keamanan pangan

\begin{tabular}{|c|c|c|c|c|c|c|c|c|}
\hline \multirow{3}{*}{ Praktik Keamanan Pangan } & \multicolumn{6}{|c|}{ Pengetahuan Gizi dan Keamanan Pangan } & \multirow{2}{*}{\multicolumn{2}{|c|}{ Total $(n=108)$}} \\
\hline & \multicolumn{2}{|c|}{ kurang } & \multicolumn{2}{|c|}{ sedang } & \multicolumn{2}{|c|}{ baik } & & \\
\hline & $\mathrm{n}$ & $\%$ & $\mathrm{n}$ & $\%$ & $\mathrm{n}$ & $\%$ & $\mathbf{n}$ & $\%$ \\
\hline sedang & 4 & 11.8 & 13 & 25.0 & 6 & 27.3 & 23 & 21.3 \\
\hline Baik & 0 & 0.0 & 4 & 7.7 & 1 & 4.5 & 5 & 4.6 \\
\hline
\end{tabular}


Hubungan yang tidak nyata antara ting kat pengetahuan gizi dan keamanan pangan dengan praktik keamanan pangan diduga karena tingkat pengetahuan bukan merupakan satu-satunya hal yang mempengaruhi praktik keamanan pangan contoh. Menurut Notoatmodjo (2007), dalam proses pembentukan dan atau perubahan, perilaku dipengaruhi oleh beberapa faktor yang berasal dari dalam dan luar individu itu sendiri. Tingkat pengetahuan gizi dan keamanan pangan merupakan faktor dari dalam individu. Dengan demikian faktor dari luar individu dapat mempengaruhi perilaku contoh terkait keamanan pangan. Faktor dari luar individu tersebut meliputi lingkungan sekitar, baik fisik maupun non-fisik seperti: iklim, manusia, sosial-ekonomi, kebudayaan, dan sebagainya.

Berdasarkan hasil analisis, sebagian besar contoh memiliki tingkat pengetahuan gizi dan keamanan pangan yang termasuk dalam kategori baik, tetapi praktik keamanan pangannya termasuk dalam kategori kurang. Menurut Notoatmodjo (2007), tindakan atau praktik seseorang tidak harus didasari oleh pengetahuan atau sikap. Hal senada juga diungkapkan oleh Sumintarsih et al. (2000) bahwa meskipun seseorang memiliki pengetahuan belum menjamin seseorang akan bertindak sesuai dengan apa yang diketahui dan dipahaminya. Green (2008) menyatakan beberapa studi perilaku termasuk perilaku keamanan pangan mengindikasikan walaupun pengetahuan merupakan komponen yang dibutuhkan untuk perubahan perilaku, tetapi hal tersebut tidak selalu cukup. Egan et al. (2006) juga mengungkapkan bahwa pengetahuan saja tidak cukup untuk dapat menghasilkan perubahan dalam praktik penanganan makanan.

\section{KESIMPULAN}

Bagian terbesar contoh (46.3\%) berpendidikan SD/sederajat. Hanya sebanyak 7.4\% contoh berpendidikan PT (Diploma/S1). Bagian terbesar contoh (31.5\%) menggunakan gerobak dorong sebagai sarana penjualan PJAS. Sebanyak $63.9 \%$ contoh menjual makanan sepinggan, $61.1 \%$ contoh menjual makanan ringan, dan $52.8 \%$ contoh menjual minuman. Sebanyak $62.0 \%$ contoh tidak pernah mengikuti penyuluhan keamanan pangan.

Bagian terbesar (48.1\%) pengetahuan gizi dan keamanan pangan contoh berkategori sedang. Pengelola kantin, contoh di Sukabumi, contoh yang berpendidikan PT, dan contoh yang pernah mengikuti penyuluhan memiliki rata-rata skor pengetahuan gizi dan keamanan pangan yang lebih baik.

Sebagian besar contoh (74.1\%) memiliki praktik keamanan pangan berkategori kurang. Sebagian besar contoh masih sangat kurang dalam praktik mencuci tangan sebelum dan setelah melayani pembeli, penggunaan BTP yang tidak sesuai ketentuan, kurangnya sarana dan fasilitas untuk mencuci peralatan dan tangan dengan air mengalir, serta ketersediaan lap bersih dan kering untuk mengeringkan peralatan yang sangat sedikit. Pengelola kantin, contoh di Sukabumi, contoh yang berpendidikan SMA, dan contoh yang pernah mengikuti penyuluhan memiliki rata-rata skor praktik keamanan pangan yang lebih baik.

Berdasarkan hasil uji beda (uji t dan one-way Anova), terdapat perbedaan pengetahuan gizi dan keamanan contoh yang nyata berdasarkan kelompok penjaja, tingkat pendidikan, dan keikutsertaan penyuluhan keamanan pangan. Terdapat perbedaan praktik keamanan pangan yang nyata berdasarkan kelompok penjaja, wilayah, dan tingkat pendidikan.

Berdasarkan hasil uji korelasi Spearman, terdapat hubungan positif yang nyata antara tingkat pendidikan dengan pengetahuan gizi dan keamanan pangan serta praktik keamanan pangan. Berdasarkan hasil uji korelasi Pearson, tidak ada hubungan yang nyata antara pengetahuan gizi dan keamanan pangan dengan praktik keamanan pangan.

\section{DAFTAR PUSTAKA}

Andarwulan N, Madanijah S, \& Zulaikhah. 2009. Laporan Penelitian: Monitoring dan Verifikasi Profil Keamanan Pangan Jajanan Anak Sekolah (PJAS) Nasional Tahun 2008. Southeast Asian Food and Agricultural Science and Technology (SEAFAST) Center IPB dan Direktorat Surveilan dan Penyuluhan Keamanan Pangan BPOM RI, Bogor.

Atmarita dan Fallah TS. 2004. Analisis situasi gizi dan kesehatan masyarakat. Dalam Soekirman et al. (Ed.), Ketahanan $\mathrm{Pa}$ ngan dan Gizi di Era Otonomi Daerah dan Globalisasi. Prosiding Widyakarya Nasional Pangan dan Gizi VIII (hlm. 153), 17-19 Mei. LIPI, Jakarta.

Contento IR. 2007. Nutrition Education: Linking Research, Theory, and Practice. Jones and Bartlett Publishers, Sudbury. 
Egan MB et al. 2006. A review of food safety and food higiene training studies in the commercial sector. Food Control, 18, 1180-1190.

Green LR. 2008. Behavioral science and food safety. J of Environmental Health, 71, 47-49.

Institute of Medicine National Research Council. 1998. Ensuring Safe Food: From Production to Consumption. National Academy Press, Washington DC.

Khomsan A. 2000. Teknik Pengukuran Pengetahuan Gizi. Jurusan Gizi Masyarakat dan Sumberdaya Keluarga, Fakultas Pertanian, IPB, Bogor.

Notoatmodjo S. 2007. Kesehatan Masyarakat: Ilmu dan Seni. Rineka Cipta, Jakarta.

Sumintarsih, Herawati I, Murtala SA, Salamun, \& Albilladiyah SI. 2000. Pengetahuan, Si- kap, Keyakinan, dan Perilaku di Kalangan Generasi Muda Berkenaan dengan Tatakrama di Kota Semarang, Jawa Tengah. Departemen Pendidikan Nasional, Direktorat Jenderal Budaya, Proyek Pengkajian dan Pembinaan Nilai-nilai Budaya, Yogyakarta.

[WHO] World Health Organization, Food Safety Unit. 1996. Persyaratan Utama Keamanan Makanan Jajanan Kaki Lima. SEAMEO TROPMED Regional Center for Community Nutrition, penerjemah. Terjemahan dari: Essential Safety Requirements for Street-vended Foods. SEAMEO Tropmed RCCN UI, Jakarta.

2000. Penyakit Bawaan Makanan: Fokus Pendidikan Kesehatan. (Hartono A, penerjemah). Widyastuti $P$ (Ed.), Foodborne Disease: A Focus for Health Education. EGC Penerbit Buku Kedokteran, Jakarta. 